УДК 624.15; 624.139

В.О. Басанський, зав. сект. , ст. наук. співр. ORCID ID 0000-0002-7850-7798

Л.М. Грубська, К.В. Гаєва інж.

ДП "НДІБВ", м. Київ,

\title{
ОСОБЛИВОСТІ ВИБОРУ ТИПУ ОГОРОДЖЕННЯ КОТЛОВАНУ ДЛЯ СПОРУДЖЕННЯ ПІДЗЕМНИХ БУДІВЕЛЬНИХ ОБ'ЄКТІВ В СКЛАДНИХ ІНЖЕНЕРНО-ГЕОЛОГІЧНИХ УМОВАХ
}

\begin{abstract}
Анотація: При виборі способу будівництва заглиблених споруд необхідно враховувати умови, в яких зводиться конструкція. Оптимізація конструктивно-технологічних рішень на етапі зведення інженерних споруд може призвести до зменшення капіталовкладень у постійні конструктивні елементи, що забезпечують стійкість конструкціи.
\end{abstract}

Ключові слова: ОГОРОДЖЕННЯ КОТЛОВАНУ, ОПТИМАЛЬНА СХЕМА

Актуальним питанням сучасного містобудування є раціональне використання території відведеної під будівництво. Розробка підземного простору дозволяє ефективно використовувати земельні ресурси.

Територія Києва і багатьох міст України має достатньо нерівномірний рельєф і складні гідрогеологічні умови, звичайно за таких умов зведення заглиблених конструкцій і експлуатація зсувних ділянок схилів у міських умовах потребує значних ресурсних витрат.

При виборі способу будівництва заглиблених споруд необхідно враховувати умови, в яких зводиться конструкція. Оптимізація конструктивно-технологічних рішень на етапі зведення інженерних споруд може призвести до зменшення капіталовкладень у постійні конструктивні елементи, що забезпечують стійкість конструкції.

При виборі конструктивно-технологічної схеми влаштування огородження котлованів в залежності від гідрогеологічних умов ділянки забудови рекомендується враховувати рекомендації наведені на рис. 1.

У наведеній схемі конструкції, що не мають достатньої щільності примикання елементів огородження (шпунти та огородження з паль) не рекомендується застосовувати для влаштування котлованів 3 рівнем грунтових вод вище днища котловану. Засто- сування цих типів огородження у таких умовах може призвести до протікань грунтових вод у котлован, суфозії часток грунту, що примикає до огородження котлованів і відповідно в якому погіршуються фізикомеханічні характеристики. Особливо ці явища можуть мати негативний прояв в умовах міської ущільненої забудови, де погіршення міцнісних характеристик грунтів основи оточуючої котлован забудови може призвести збільшення осідань і деформацій цих будівель і споруд.

Також на вибір типу огородження у складних інженерно-геологічних умовах та в умовах ущільненої забудови впливають додаткові фактори, що характеризують різні типи огородження котлованів, а саме:

- грунтові умови ділянки забудови (типи грунтів);

- водопроникливість огородження;

- міцність і жорсткість огородження;

- поглинання шуму та вібрації;

- вплив на оточуючу забудову;

- можлива глибина котловану;

- швидкість будівництва;

- можливість сприйняття навантаження від будівлі;

- економічність.

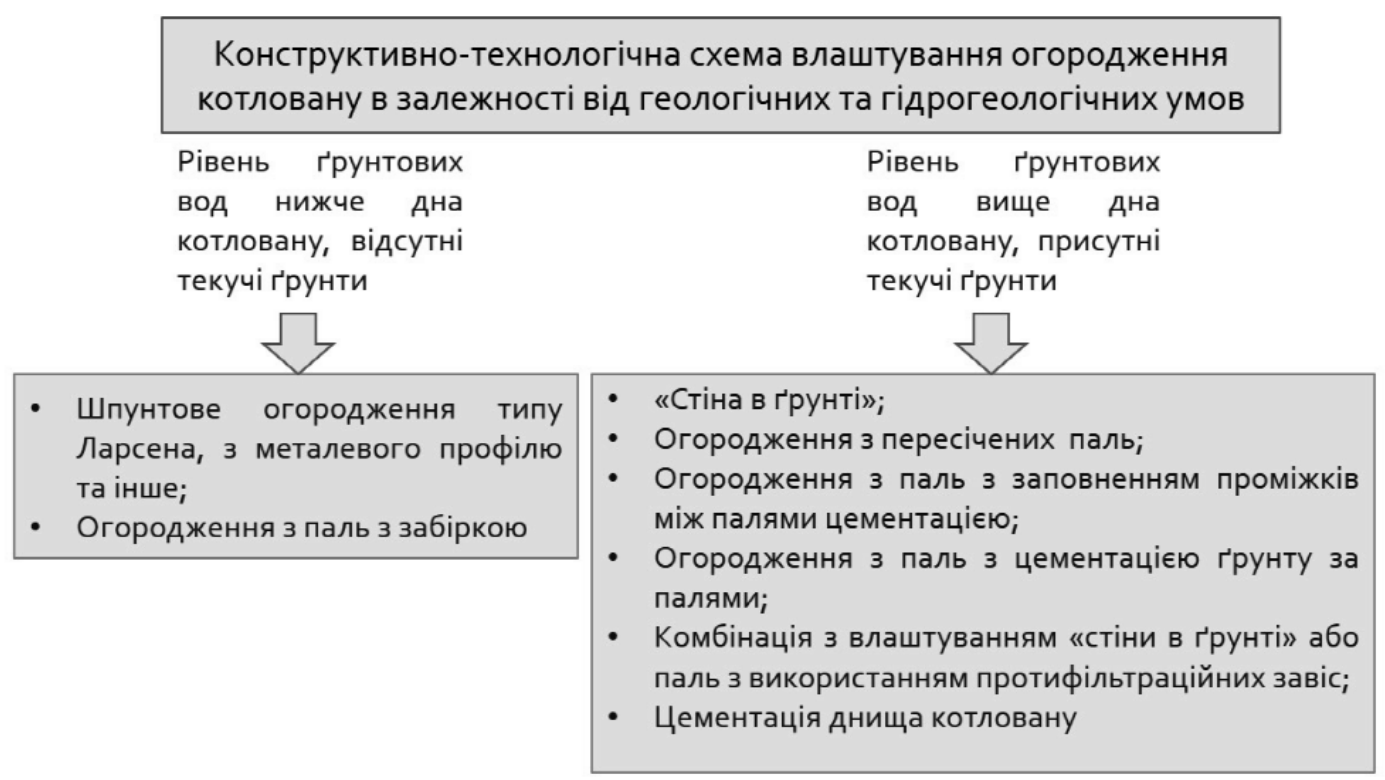

Рис. 1. Алгоритм вибору конструктивно-технологічного типу огородження котловану в залежності від рівня грунтових вод 


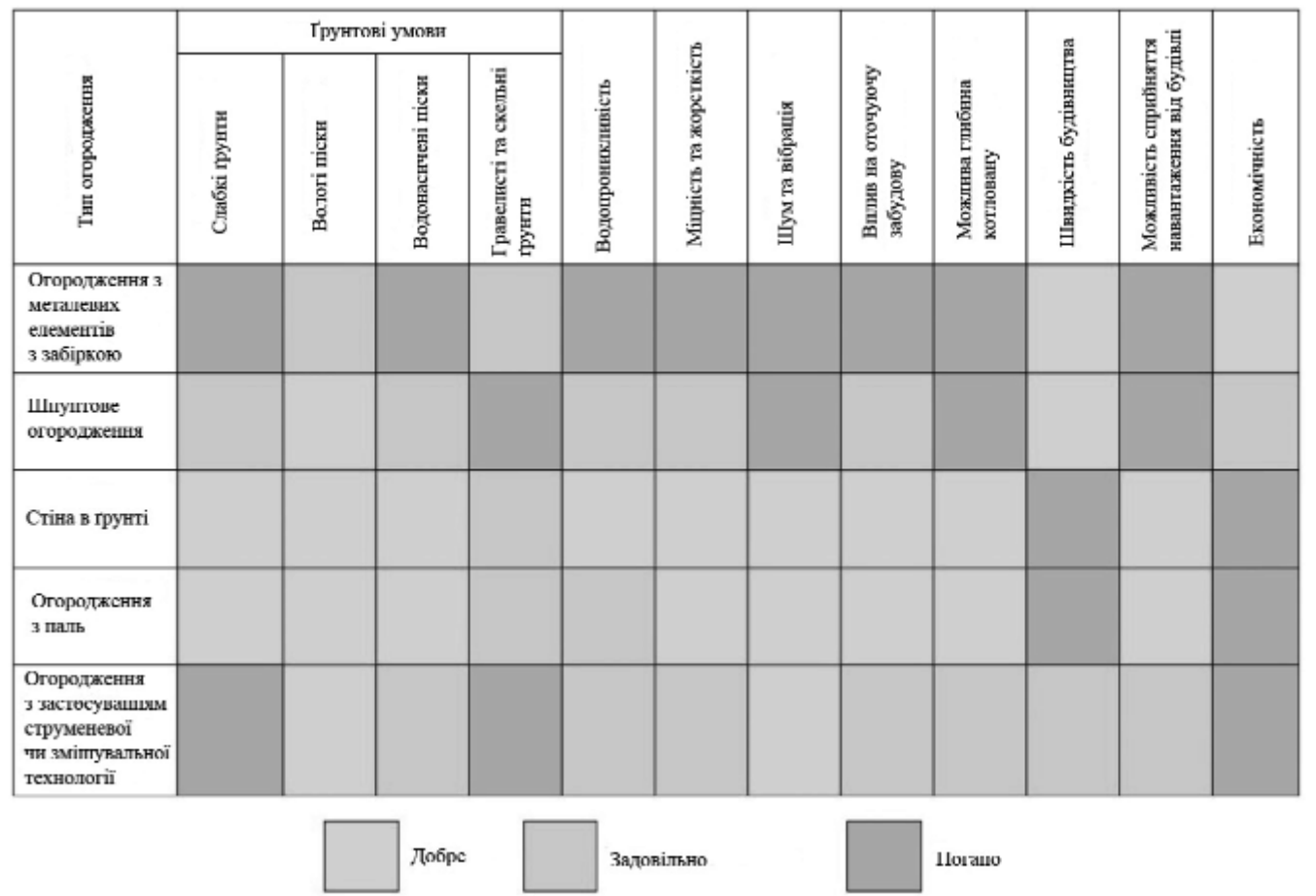

Рис. 2. Співставлення техніко-економічних показників типів огородження котлованів

Перелічені фактори суттєво впливають на техніко-економічні показники типів огородження котлованів. На рис. 2 наведено співставлення техніко-економічних показників різних типів огородження в залежності від перелічених умов.
Висновки: Застосування наведеного співставлення дозволяє прийняти рішення про застосування оптимальної конструктивно-технологічної схеми влаштування огородження котлованів в залежності від гідрогеологічних умов ділянки забудови та інших факторів.

\title{
תimepamypa
}

1. Возведение сооружений методом "стена в грунте". Под ред. докт. техн. наук проф. А. Л. Филахтова. Киев - 1976.

2. Портовые гидротехнические сооружения. Под ред. проф. В.Е. Ляхницкого. Москва - 1968.

3. Справочник проектировщика. Основания, фундаменты и подземные сооружения. Москва - 1985.

\section{Reference}

1. The construction of structures by the "Wall in the ground." Ed. Dr. tech. Sciences prof. A.L. Filakhtova. Kiev - 1976.

2. Port hydraulic structures. Ed. prof. V.E. Lyakhnitsky. Moscow - 1968.

3. Reference Designer. Foundations, foundations and underground structures. Moscow - 1985.

В.А. Басанский, ORCID ID 0000-0002-7850-7798, зав. сект. ГП ”НИИСП”, г. Киев

\section{ОСОБЕННОСТИ ВЫБОРА ТИПА ОГРАЖДЕНИЯ КОТЛОВАНОВ ДЛЯ СТРОИТЕЛЬСТВА ПОДЗЕМНЫХ СТРОИТЕЛЬНЫХ ОБЬЕКТОВ В СЛОЖНЫХ ИНЖЕНЕРНО- ГЕОЛОГИЧЕСКИХ УСЛОВИЯХ}

\author{
Аннотащия: При выборе способа строительства заллубленных сооружений необходимо учитывать \\ условия, в которых сводится конструкиия. Оптимизация конструктивно-технологических решений \\ на этапе возведения инженерных сооружений может привести к уменьшению капиталовложений 8 \\ постоянные конструктивные элементы, обеспечивающие устойчивость конструкиии. \\ Ключевые слова: ОГРАЖДЕНИЯ КОТЛОВАНОВ, ОПТИМАЛЬНЫЕ СХЕМЫ \\ V.O. Basanskyi, ORCID ID 0000-0002-7850-7798, Head of the sector

\section{FEATURES OF THE SELECTION OF THE TYPE OF PROTECTION OF KITCHENS FOR THE CONSTRUCTION OF UNDERGROUND CONSTRUCTION OBJECTS IN COMPLEX ENGINEERING-GEOLOGICAL CONDITIONS}

Annotation: When choosing a method for constructing buried structures, it is necessary to consider the conditions in which the structure is reduced. Optimization of constructive-technological solutions at the stage of construction of engineering structures can lead to a decrease in investment in permanent structural elements that ensure the stability of the structure.

Key wrds: COILED FENCES, OPTIMAL SCHEMES 